\title{
Chemical composition of Salvia officinalis I. essential oil from Bulgaria
}

\section{Stanka Damyanova ${ }^{1}$, Silvia Mollova², Albena Stoyanova ${ }^{3}$, Oleksii Gubenia ${ }^{4}$}

\author{
1 - University of Russe, Branch - Razgrad, Bulgaria \\ 2 - Institute of Rose, Kazanlik, Bulgaria \\ 3 - University of Food Technologies, Plovdiv, Bulgaria \\ 4 - National University of Food Technologies, Kyiv, Ukraine
}

\section{Keywords:}

Salvia officinalis

Essential oil

Composition

Bulgaria

\section{Article history:}

Received 14.09.2016

Received in revised form 13.11.2016

Accepted 27.12.2016

Corresponding author:

Stanka Damyanova

E-mail:

sdamianova@uni-ruse.bg

DOI: $10.24263 / 2304-$ 974X-2016-5-4-8

\section{Abstract}

Introduction. The objectivs of this study is to present the chemical composition of Salvia officinalis essential oil from Bulgaria.

Materials and methods. The herb from salvia was used from the market. The essential oil was obtained by hydrodistillation for $3 \mathrm{~h}$ in laboratory glass apparatus. The chemical composition of the oil was determined chromatographically.

Result and discussion. The moisture of the plant was $12.16 \%$ and the yield of essential oil is $0.93 \%$.

Twenty-eight components were identified in the oil.

The main compounds of essential oil were as follows: $\alpha$-thujone (26.68\%), (E)- $\beta$-caryophyllene (7.47\%), 1,8cineole $(7.19 \%), \alpha$-humulene $(6.11 \%), \beta$-pinene $(5.44 \%)$, $\beta$-thujone $(5.35 \%)$, camphor $(4.84 \%)$, allo-aromadendrene (4.55\%), borneol $(3.69 \%)$, and $\alpha$-pinene $(3.58 \%)$. Three groups of compounds were found in hydrodistillated sage oil. The total oxygen-containing monoterpenes constituted the highest percentage of the components of the essential oil constituting 59.15\%, followed by sesquiterpene hydrocarbons $(24.37 \%)$ and monoterpene hydrocarbons $(14.66 \%)$. The oxygen-containing monoterpene fraction was most abundant in the oil and it was particularly rich in ketones $(70.96 \%$ of this fraction)

Conclusion. It can be stated that a number of oxygencontaining monoterpenes, sesquiterpene hydrocarbons and monoterpene hydrocarbons were detected in S. officinalis essential oil. 


\section{Introduction}

The family of Lamiaceae consist of about 230 genera. Many species from this family are considered of high importance because of their uses in medicine, culinary and cosmetics, and production of essential oil. Same of the major genera belonging to Lamiaceae family is Salvia.

About 900 species of the genus Salvia are cultivated throughout the world. The commercial oil is produced mainly by S. officinalis L. (sage) and S. sclarea L. (clary sage).

Sage (Salvia officinalis L.) is a common herbal plant widely cultivated in varios parts around the world, but it is native in East Mediterranean region. It is typically cultivated in temperate climatic areas where is abundant sunlight.

The preparation of dried herb of sage is registered as a medicinal drug. Phytochemical investigation of sage revealed a great number of bioactive compounds, among which the most important are essential oil and polyphenol compounds.

A previous studies have revealed $\alpha$-thujone, 1,8-cineole, $\beta$-pinene, $\beta$-thujone, camphor and borneol to be the major constituents of the sage essential oil $[1,2,3,4,5,6,8,11,14$, $15,16,18,19,20,21]$.

Different chemotypes have been described for sage: 1 . camphor $>\alpha$-thujone $>1,8$ cineole $>\beta$-thujone; 2 . camphor $>\alpha$-thujone $>\beta$-thujone $>1,8$-cineole; $3 . \beta$-thujone $>$ camphor $>1,8$-cineole $>\alpha$-thujone; 4. 1,8-cineole $>$ camphor $>\alpha$-thujone $>\beta$-thujone; 5 . $\alpha$-thujone $>$ camphor $>\beta$-thujone $>1,8$-cineole [9].

ISO 9909:1997 [10] for medicinal uses regulates the amounts of the following constituents in the essential oil: cis-thujone (18.0-43.0\%), camphor (4.5-24.5\%), 1,8cineole (5.5-13.0\%), trans-thujone (3.0-8.5\%), $\alpha$-humulene ( $\leq 12.0 \%), \alpha$-pinene $(1.0-6.5 \%)$, camphene $(1.5-7.0 \%)$, limonene $(0.5-3.0 \%)$, bornyl acetate $(\leq 2.5 \%)$ and linalool+linalyl acetate $(\leq 1.0 \%)$.

Sage essential oil and extracts have been used for thousands of years in folk medicine [9].

Essential oil distinguishes itself by an olfactory bouquet with camphor and thujone-like notes. This kind of fragrance is highly appreciated in compositions with herbal and spicy character, and is especially favored in the creation of masculine-type perfumes. The characteristic aromatic-herbal complex of the oil is also of a particular interest to the development of aromatic compositions for food industry - typically for canned fish and meat products [9].

More recently, studies on the biological activity of sage showed that the essential oil and some of its constituents possess god antimicrobial activity with respect to bacteria, yeast and fungi involved in food spoilage $[1,2,3,11,12,13]$.

The aim of present study was producing of the sage essential oil and determination of their chemical composition.

\section{Materials and methods}

In the investigation was used herb from sage (Salvia officinalis L.) from the market.

The row material moisture content was determined by drying up to constant weight, at $105^{\circ} \mathrm{C}[17]$. 
The essential oil was obtained from the cut $(1-2 \mathrm{~cm})$ aerial parts $(100 \mathrm{~g})$ by hydrodistillation for $3 \mathrm{~h}$ in laboratory glass apparatus of British Pharmacopoeia, modified by Balinova and Diakov [7]. The oil was dried over anhydrous sulfate and stored in tightly closed dark vials at $4{ }^{\circ} \mathrm{C}$ until analysis.

GC analysis was performed using gas chromatograph Agilent 7890A; column HP-5 ms (30m x $250 \mu \mathrm{m} \times 0,25 \mu \mathrm{m}$ ); temperature: $35^{\circ} \mathrm{C} / 3 \mathrm{~min}, 5{ }^{\circ} \mathrm{C} / \mathrm{min}$ to $250{ }^{\circ} \mathrm{C}$ for $3 \mathrm{~min}$, total 49 min; carrier gas helium $1 \mathrm{ml} / \mathrm{min}$ constant speed; split ratio 30:1. GC/MS analysis was carried out on a mass spectrometer Agilent 5975C, carrier gas helium, column and temperature as the same as the $\mathrm{GC}$ analysis.

The identification of chemical compounds was made by comparison to their relative retention time and library data. The identified components were arranged in order to the retention time and quantity in percentage.

\section{Results and discussion}

The moisture of the plant was $12.16 \%$.

The essential oil obtained from sage with a yield of $0.93 \%$ (in abs. dry mass) was a yellowish liquid with a warm camphoraceous, thujone-like odor and taste. The difference in the yield of the oil and the reported data may be due to the climatic conditions in the respective locality in which the plant is growing and the part of the plant processed.

The list of the compounds, in order of elution, and the quantitative data, expressed as area percentage, was reported in Table 1 . As seen 28 components representing $88.75 \%$ of the total content were identified in the oil. Thirteen of them were in concentrations over $1 \%$ and the rest 15 constituents were in concentrations under $1 \%$.

As seen the major constituents (up 3\%) of the oil were as follows: $\alpha$-thujone (26.68\%), (E)- $\beta$-caryophyllene (7.47\%), 1,8-cineole (7.19\%), $\alpha$-humulene (6.11\%), $\beta$-pinene $(5.44 \%)$, $\beta$-thujone (5.35\%), camphor (4.84\%), allo-aromadendrene (4.55\%), borneol (3.69\%), and $\alpha$-pinene (3.58\%).

The difference in the quantities of chemical composition of the our essential oil and the reported data may be due to environmental conditions under which the plant has grown as well as the variation in conditions of analysis.

The chromatographic profile showed a complex mixture of components. The classification of the identified compounds, based on functional groups, was summarized in Table 1. The total oxygen-containing monoterpenes constituted the highest percentage of the components of the essential oil constituting $59.15 \%$, followed by sesquiterpene hydrocarbons (24.37\%) and monoterpene hydrocarbons (14.66\%). The percentage of aliphatic hydrocarbons, oxygen-containing sesquiterpenes and phenyl propanoids were under $1 \%$.

The oxygen-containing monoterpene fraction was most abundant in the oil and it was particularly rich in ketones ( $70.96 \%$ of this fraction) (Figure 1).

The ketones and cyclic ethers were the main groups of compounds responsible for the characteristic odor of sage oil and their concentrations were similar to those regulated by ISO 9909:1997 [10]. 
Percentage composition of the essential oil of

Table 1

Salvia officinalis $L$.

\begin{tabular}{|c|c|c|c|}
\hline $\mathbf{N}$ & Components & RI & Content \\
\hline 1 & (Z)-salvene & 849 & 0.39 \\
\hline 2 & (E)-salvene & 858 & 0.11 \\
\hline 3 & $\alpha$-Pinene & 939 & 3.58 \\
\hline 4 & Camphene & 953 & 0.75 \\
\hline 5 & $\beta$-Pinene & 980 & 5.44 \\
\hline 6 & Myrcene & 991 & 0.67 \\
\hline 7 & $\alpha$-Terpinene & 1018 & 0.29 \\
\hline 8 & $p$-Cymene & 1026 & 0.18 \\
\hline 9 & Limonene & 1030 & 2.02 \\
\hline 10 & 1,8-Cineole & 1032 & 7.19 \\
\hline 11 & $\gamma$-Terpinene & 1061 & 0.26 \\
\hline 12 & $\alpha$-Thujone & 1098 & 26.68 \\
\hline 13 & $\beta$-Thujone & 1112 & 5.35 \\
\hline 14 & Camphor & 1141 & 4.84 \\
\hline 15 & (E)-Pinocamphone & 1160 & 0.38 \\
\hline 16 & Borneol & 1165 & 3.69 \\
\hline 17 & Terpinen-4-ol & 1178 & 0.45 \\
\hline 18 & $\alpha$-Terpineol & 1189 & 0.29 \\
\hline 19 & Bornyl acetate & 1284 & 3.62 \\
\hline 20 & (E)- $\beta$-caryophyllene & 1418 & 7.47 \\
\hline 21 & $\alpha$-Humulene & 1455 & 6.11 \\
\hline 22 & allo-Aromadendrene & 1465 & 4.55 \\
\hline 23 & $\gamma$-Muurolene & 1477 & 0.43 \\
\hline 24 & Viridiflorene & 1494 & 2.52 \\
\hline 25 & $\gamma$-Cadinene & 1513 & 0.18 \\
\hline 26 & $\delta$-Cadinene & 1524 & 0.37 \\
\hline 27 & Ledol & 1568 & 0.53 \\
\hline 28 & Caryophyllene oxide & 1583 & 0.41 \\
\hline & & Total & 88.75 \\
\hline \multicolumn{3}{|c|}{ Oxygen-containing monoterpenes } & 59.15 \\
\hline \multicolumn{3}{|c|}{ Sesquiterpene hydrocarbons } & 24.37 \\
\hline \multicolumn{3}{|c|}{ Monoterpene hydrocarbons } & 14.66 \\
\hline \multicolumn{3}{|c|}{ Aliphatic hydrocarbons } & 0.56 \\
\hline \multicolumn{3}{|c|}{ Oxygen-containing sesquiterpenes } & 1.06 \\
\hline \multicolumn{3}{|c|}{ Phenyl propanoids } & 0.20 \\
\hline
\end{tabular}




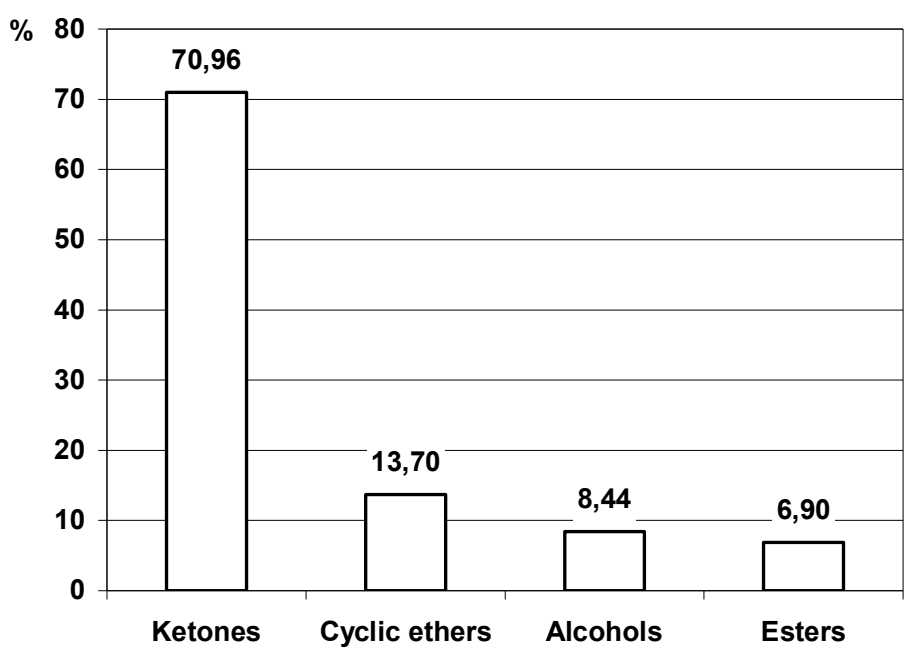

Figure 1. Oxygen-containing monoterpene fraction

\section{Conclusion}

It can be stated that a number of oxygen-containing monoterpenes, sesquiterpene hydrocarbons and monoterpene hydrocarbons were detected in S. officinalis essential oil.

\section{References}

1. Abu-Darwish M., Cabral C., Ferreira I., Goncalves M., Cavaleiro C., Cruz M., AlBdour T., Salguero I. (2013), Essential oil of common sage (Salvia officinalis L.) from Jordan: Assessment of safety in mammalian cells and its antifungal and antiinflammatory potential, BioMed Research International, pp. 1-9.

2. Alizadeh A., Shaabani M. (2012), Essential oil composition, phenolic content, antioxidant and antimicrobial activity in Salvia officinalis L. cultivated in Iran, Advances in Environmental Biology, 6, pp. 221-226.

3. Altun M., Ünal M., Kocagöz T., Gören A. (2007), Essential oil compositions and antimicrobial activity of Salvia species, Journal of Essential Oil Bearing Plants, 10, pp. 251-258.

4. Archana P., Negi K., Dutta M. (2013), Variability in essential oil composition of sage (Salvia officinalis L.) grown under North Western Himalayan region of India, Journal of Medicinal Plant Research, 7, pp. 683-688.

5. Asllani U. (2000), Chemical composition of Albanian sage oil (Salvia officinalis L.), Journal of Essential Oil Research, 12, pp. 79-84.

6. Awen Z., Unnithan C., Ravi S., Kermagy A., Prabhu V., Hemlal H. (2011), Chemical composition of Salvia officinalis essential oil of Libya, Journal of Essential Oil Bearing Plants, 2011, pp. 89-94.

7. Balinova A., Diakov G. (1974), On improved apparatus for microdistillation of rose flowers, Plant Science, pp. 79-85. 
8. Bernotiene G., Nivinskiene O., Butkiene R., Mockute D. (2007), Essential oil composition variability in sage (Salvia officinalis L.), Chemija, 18, pp. 38-43.

9. Georgiev E., Stoyanova A. (2006), A guide for the specialist in aromatic industry, Plovdiv.

10. ISO 9909 (1997), Oil of Dalmatian sage (Salvia officinalis L.).

11. Miguel G., Cruz C., Faleiro M., Simões M., Figueiredo A., Barroso J., Pedro L. (2011), Salvia officinalis L. essential oils: effect of hydrodistillation time on the chemical composition, antioxidant and antimicrobial activities, Natural Product Research: Formerly Natural Product Letters, 25, pp. 526-541.

12. Miladinovic D., Miladinovic L. (2000), Antimicrobial activity of essential oil of sage from Serbia, Physics and Technology, 2, pp. 97--100.

13. Pop A.-M., Muste S., Mureşan C., Pop C., Salanta L. (2013), Comparative study regarding the importance of sage (Salvia officinalis L.) in terms of antioxidant capacity and antimicrobial activities, Hop and Medicinal Plants, 41, pp. 66-74.

14. Porte A., Godoy R., Maia-Porte L. (2013), Chemical composition of sage (Salvia officinalis L.) essential oil from the Rio de Janeiro state (Brazil), A Revista Brasileira de Plantas Medicinais, 15, pp. 438-441.

15. Raal A., Orav A., Arak E. (2007), Composition of the essential oil of Salvia officinalis L., from various European countries, Natural Product Research, 21, pp. 406-411.

16. Rajabi Z., Ebrahimi M., Farajpour M., Mirza M., Ramshini H. (2014), Compositions and yield variation of essential oils among and within nine Salvia species from various areas of Iran, Industrial Crops and Products, 61, pp. 233-239.

17. Russian Pharmacopoeia. (1 ${ }^{\text {th }}$ Edition), (1990), Moscow.

18. Tsankova E., Konaktchiev A., Genova E. (1994), Constituents of essential oils from three Salvia species, Journal of Essential Oil Research, 6, pp. 375-378.

19. Tucker A., Maciarello M. (2011), Essential oils of cultivars of Dalmatian sage (Salvia officinalis L.), Journal of Essential Oil Research, 2, pp. 139-144.

20. Vera R., Chane-Ming J., Fraisse D. (1999), Chemical composition of the essential oil of sage (Salvia officinalis L) from Reunion Island, Journal of Essential Oil Research, 11, pp. 399-402.

21. Vernin G., Metzger J. (1986), Analysis of sage oils by GC-MS data bank - Salvia officinalis L. and Salvia lavendulifolia Vahl., Perfumery and Flavorist, 11, pp. 79-84. 